بسم الله الرحمن الرحيم

من تطبيقات المجال الدلالي

(1) (كناشات دلالية )

لفظ الكناش ليس عربيا ، قال الخفاجي : أنه لفظ سريا في معناه المجموعة أو التذكرة .

فإذا كاتت لفظة الكناش تعني المجموعة ولفظ المجالي الدلالي تعني اندراج مجموعة كلمات تحت لفظ عام ، فمن المكن تسمية البحث : كناشات دلالية دراسة تطبيقية للمجال الالالي.

والدراسة الدالية تعتبر نظرية للمعنى اللغوي ، أي تور حول مفهوم الكلمة من

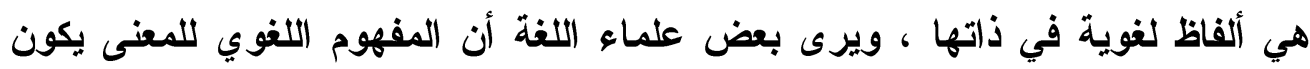

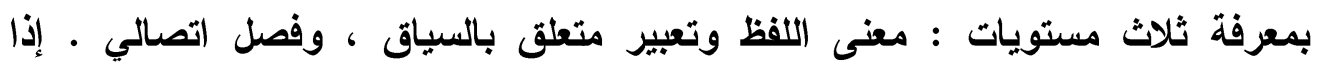

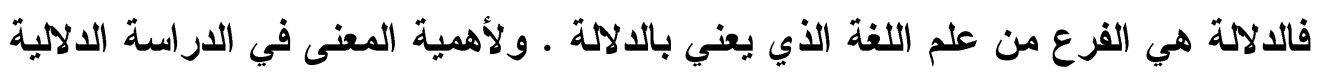

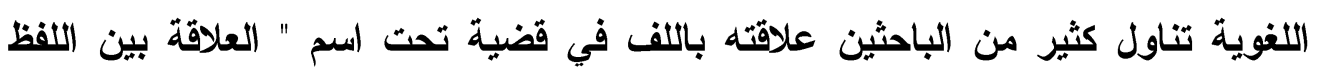
والمعنى " أو علاقة الألفاظ بمدلولاتها ، وذلك من خلال بحوث مستفيضة بين القدماء و والمحثثين .

واللغة ألفاظ ذات معان يتفاهم بها الناس ، فالألفاظ شطر اللفة والمعاني طرها

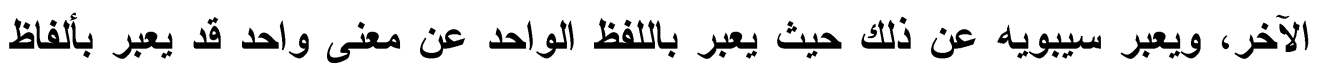

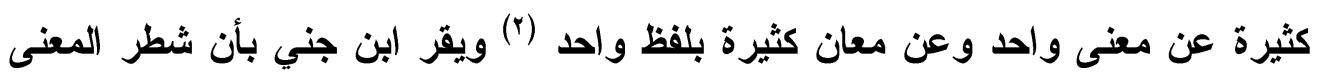

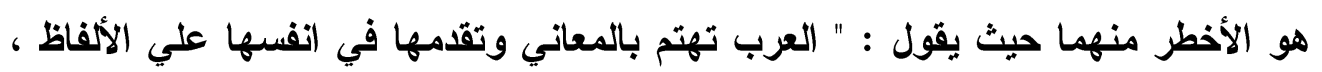
وأن العرب انما تحلى الفاظها وتدبجها وتثيها وتزخرفها عناية بالمعاني التي وراءها

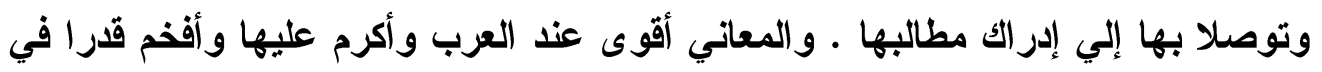
نفوسها ـ والألفاظ خدم المعاني ، والمخدوم - لاش ك - أشرف من الخادم " (r) .

' ' ' لفظ الكناثات : من كتاب الكناش في الحو و التصريف لأبي الفذاء تحقيق د / جودة مبروك محمد .

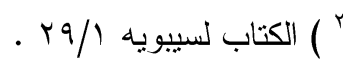

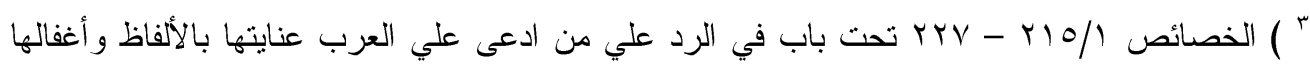
المعاني . 
وتتضح أهمية اللفظ في تعريف ابن جني للغة فهي عنده أصوات يعبر بها كل

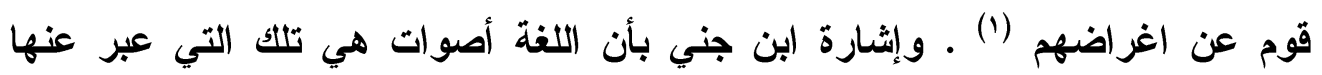

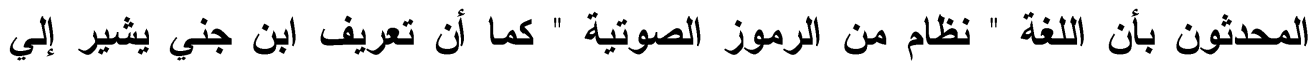

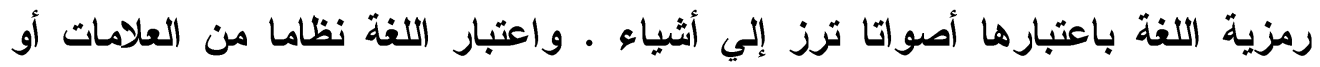

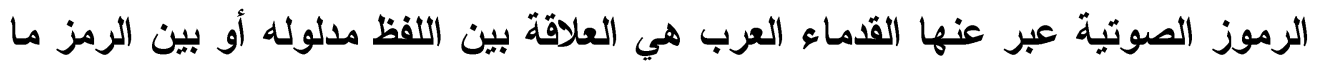
يرمز إليه . هذا وقد أوضح الجاحظ أساس دراسة المعنى دراسة علمية ، فهو يشير إلي أن

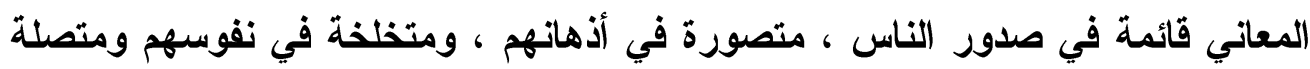
بخو اطرهم ، ..... ويحيي تلك المعاني ذكرهم لها واخبارهم عنها ، واستعمالهم أياها ....

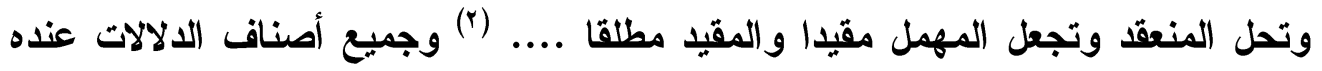
علي المعاني من لفظ وغير لفظ خمسة أثياء لا تنمقص ولا تزيد أولها اللفظ ثم الإشارة ثم العقد ثم الخط ثم الحال التي تسمى نصبه ، وبالتالي يصبح اللفظ أساسا للالالة اللفظية

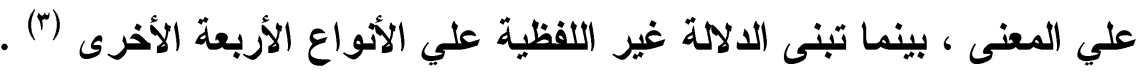
هكذا أوضح الجاحظ أساس دراسة المعنى دراسة علمية ، ذلكى أن النواة

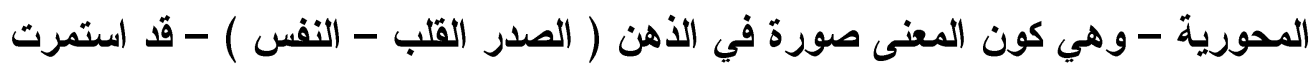
حتى صارت هي محور نظرية المعنى اللغوي ـ وممن تناول القدماء تناولا يربط اللفظ

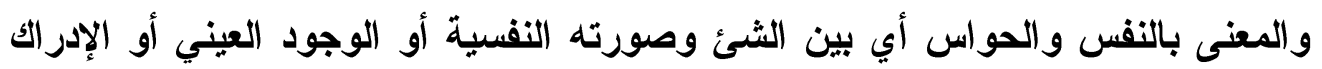

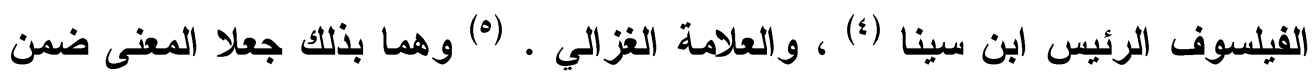

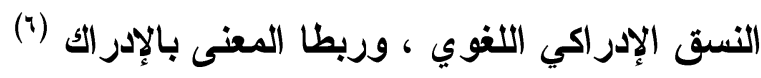

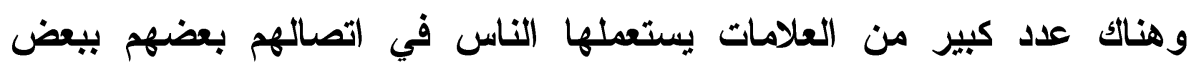

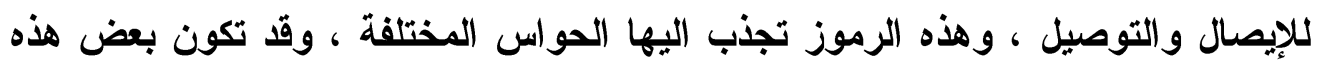

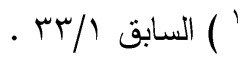

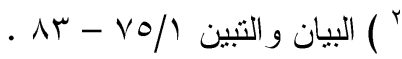

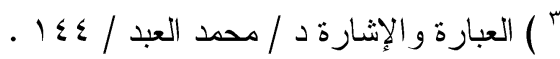

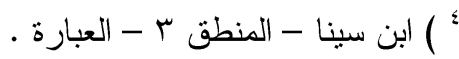

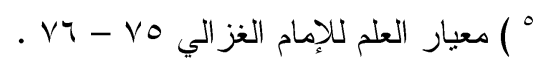

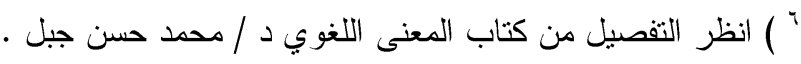

$$
\begin{aligned}
& \text { - rON - }
\end{aligned}
$$


الرموز مفردة أو وحيدة وقد تكون مركبة معقدة ، والألفاظ أو الكلمات هي احدى العلامات

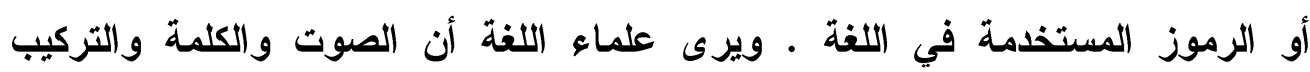
النحوي ما هي إلا وحدات للكلام المتصل باللغة .

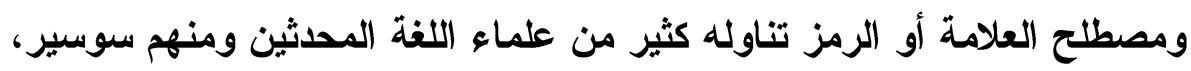
وهو عنده ذو جانبين الفكر والصورة الصوتية ، أي توحد الجانبين في العقل (1) ويتناول

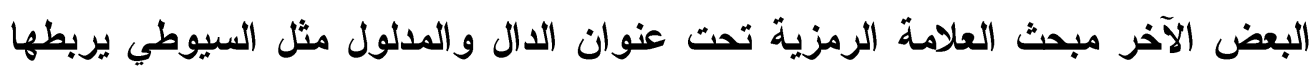
بنشاة اللغة ، ويعقد لها ابن جني في خصائصه أبو ابا كاملة مثل باب المناسبة بين الألفاظ

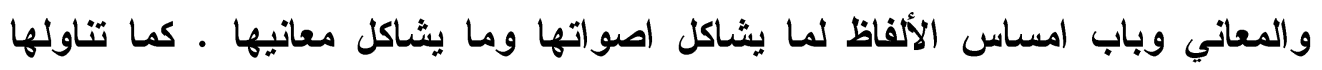

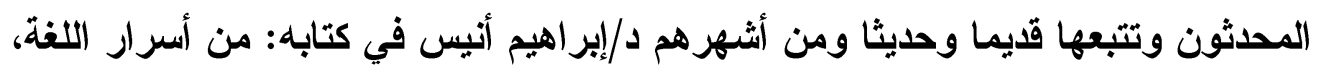

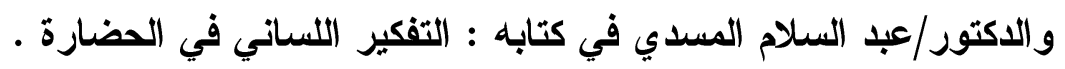

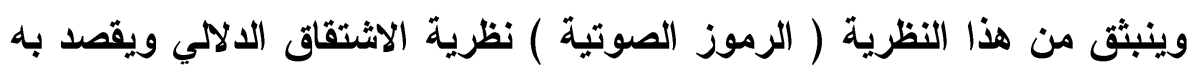

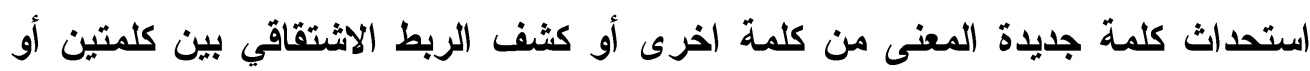

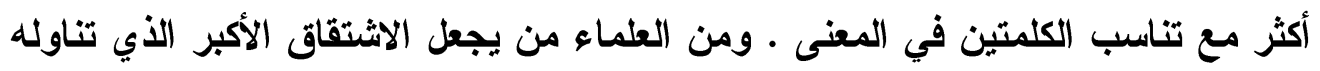

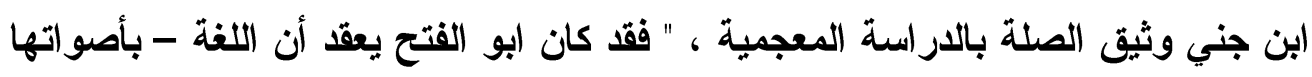

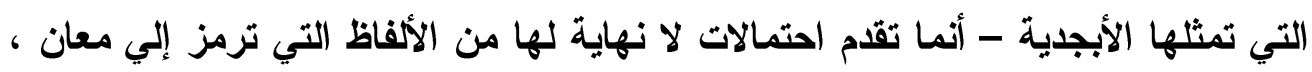

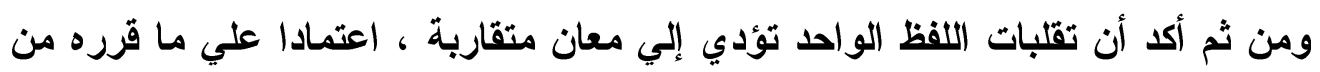
وجود علاقة بين اللفظ ومدلوله ، وهذه الطريقة في محاولة الوصول إلي الاحتمالات

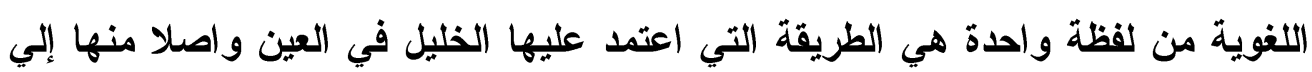

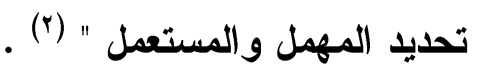

وإذا توسعنا في الاشتقاق الأكبر فبعد أن كان علي مستوى الكلمة الواحدة اصبح

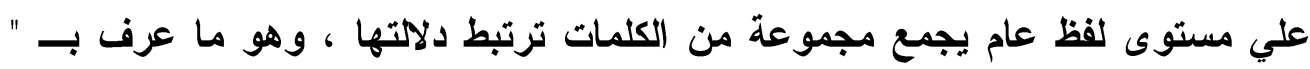

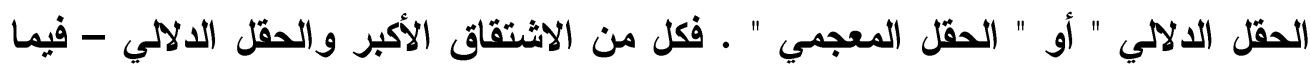

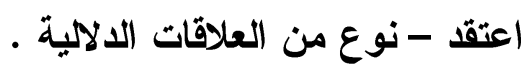

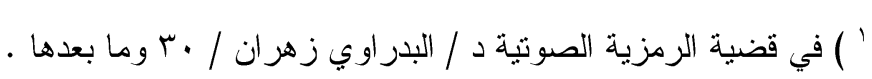

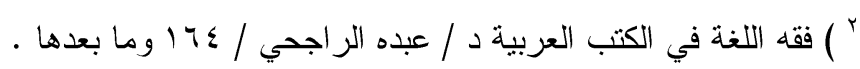

$$
\begin{aligned}
& \text { - ro9 - }
\end{aligned}
$$


و الحقل ما هو إلا نمط من الأمماط المختلفة لعلاقات دلالية بين معاني الفاظ لفوية

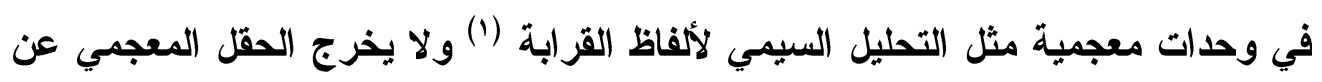

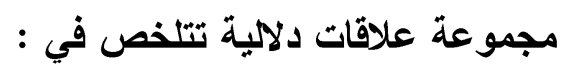

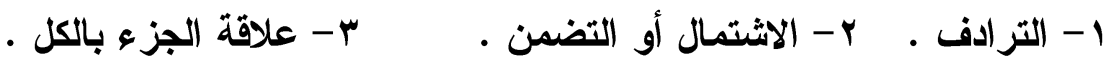

$$
\begin{aligned}
& \text { ه - التنافر . (r) } \\
& \text { ع - التضاد . }
\end{aligned}
$$

ويرى د/منقور عبد الجليل أن الآمدي هو صاحب السبق فيما يسى الآن بنظرية

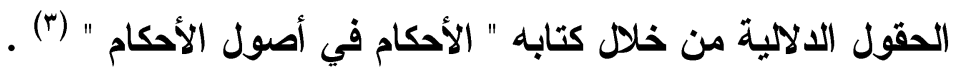

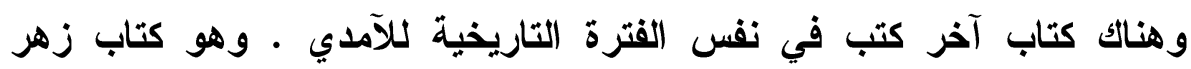
الربيع، مختصر ربيع الأبرار للزمخري ، وكتاب زهر الربيع للإمام ممد بن أبي بكر فهر

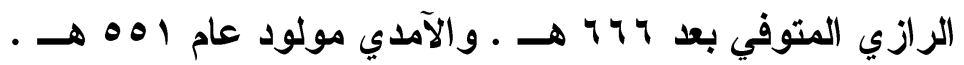
وقد نسق الزمخشري كتابه علي اثنين وتسعين باب منها باب العوالم الكونية

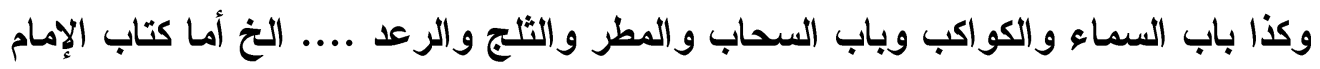

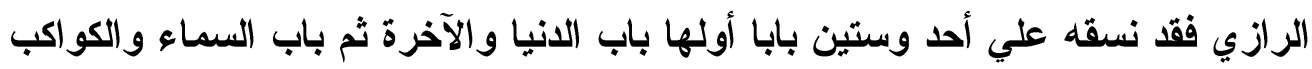

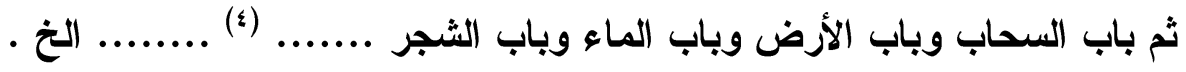
وإذا كان المفهوم اللفوي للمعنى يكون بمعرفة معنى اللفظ والسياق فإن علماء

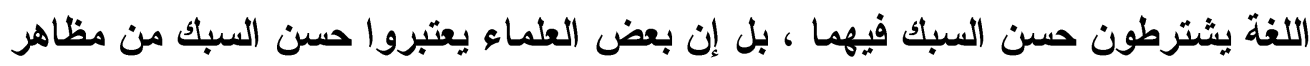

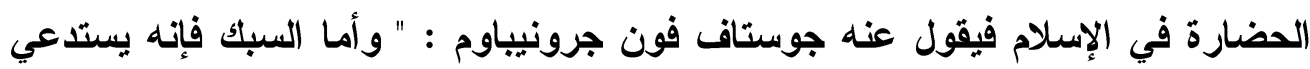
بل يكاد يتضمن - اختبار ما هو ممتاز واختيار الأديب - أي ألفاظه - يكثف عن عن مجال ولمال

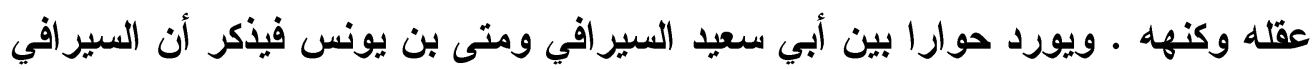

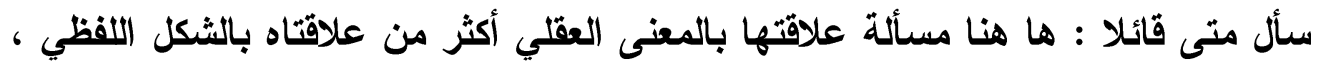

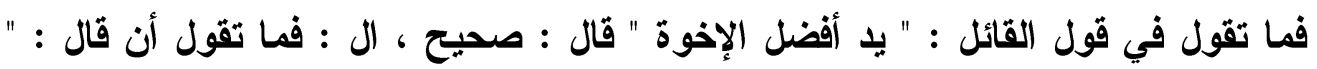

$$
\begin{aligned}
& \text { ' ' ) انظر علم الدلالة لسبستيان لوبنز ترجمة د / سعيد بحيري / عهب . }
\end{aligned}
$$

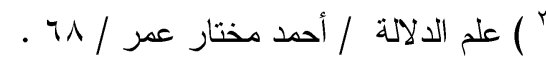

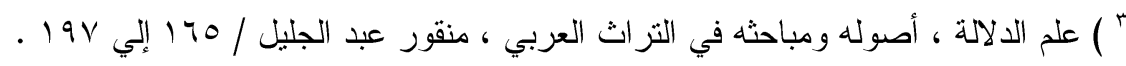

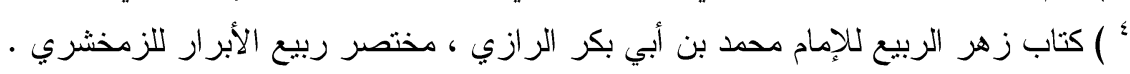

$$
\begin{aligned}
& \text { - ب4. - }
\end{aligned}
$$


زيد أفضل أخواته " ؟ قال : صحيح قال : فما الفرق بينهما علي الصحة ؟ فبلج متى

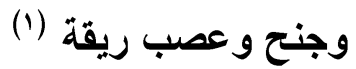
ثم يوضح المظهر الحضاري للعالم - ومنهر علماء اللغة - مقصورة علي أدائه دوره بوصفه حارسا علي شريعة الدين وعلومه ـ ويورد نصيحة لابن السيكت للمتأدبين

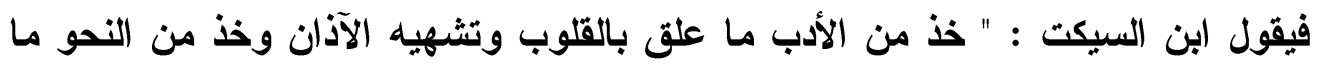

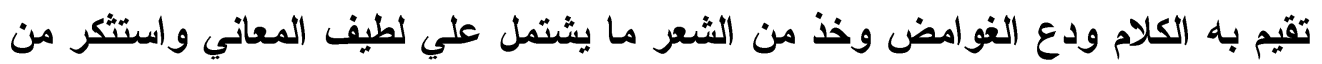

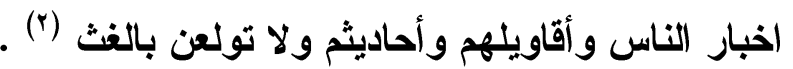

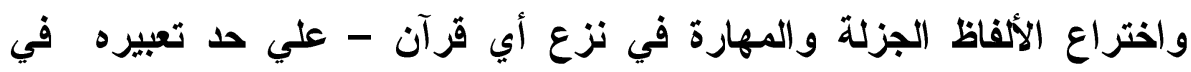

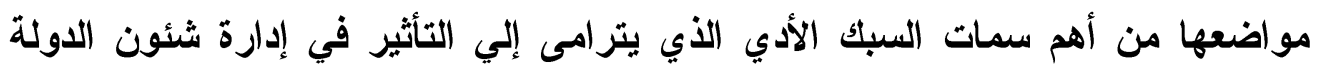

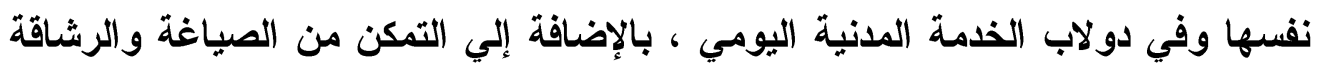

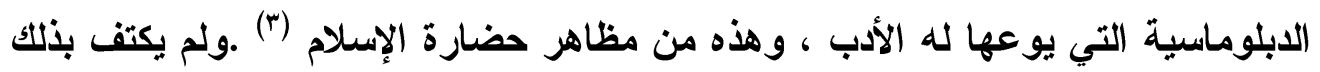

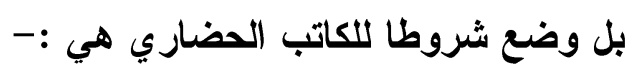

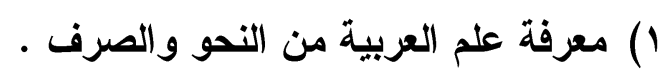

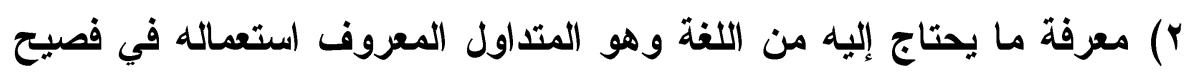

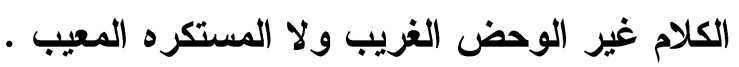

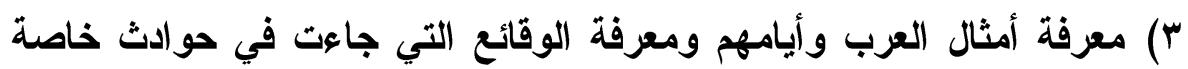

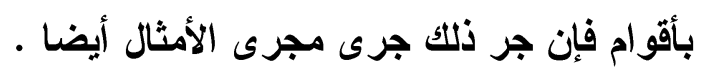

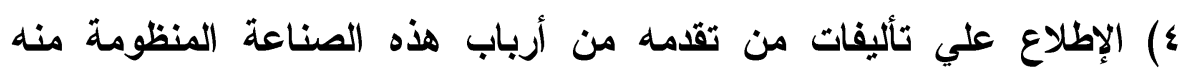

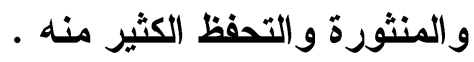

•) معرفة الأحكام السلطانية .

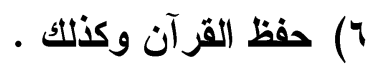

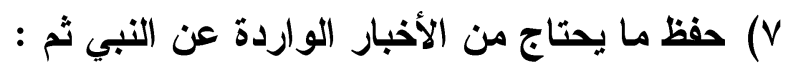

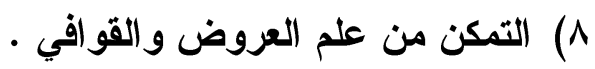


ثم يذكر أن الأدب والسبك الأدبي ، وهما أمران يتماثل تأثيرهما إلي حد كير في

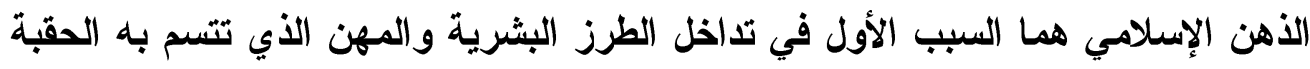
الأخيرة من العصور الوسطى • والمؤلف بألك يبين العلاقة الوثيقة بين الأدب ( معنى ولفا ) وبين مظاهر حضارة الإسلام .

بل أن المؤلف يجمع بين الحقيقة والرمز وبين الصوت والمعنى ، فيقول : والثغرة التي تفصل بين الحقيقة والرمز وبين الصوت والمعنى يتظلب عليها بخلع تجارب (النفس (1)

والموضوع الأساسي للاراسة الدلالة هو المعنى ولا يستطيع أمر إنكار قيمة

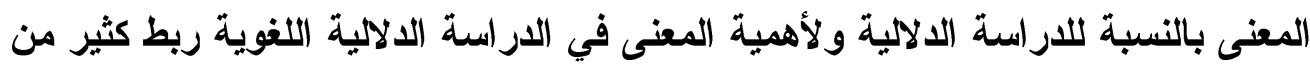

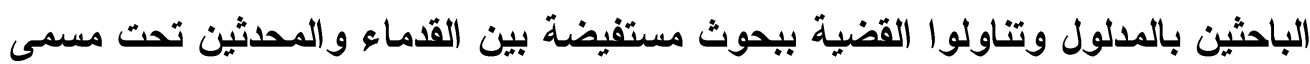

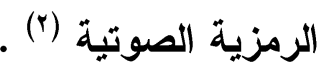

أما بالنسبة للتحليل الدلالي فأصبحت النظرة إليه الآن علي أنه يتناول فرعين : 1-بيان معاني المفردات حين تعمل الوحدات اللغوية كرموز الأشياء خارج الائرة

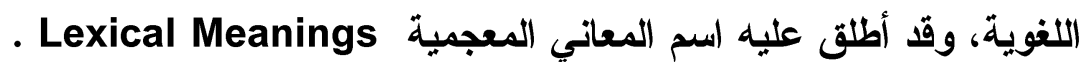
r-بيان معاني الجمل والعبارات أو العلاقات بين الوحدات اللغوية مثل المورفيمات و الكلمات والجميل، وقد سماها بعضهم المعاني النحوية Syntactic Meanings ومن نظريات التحليل اللغوية التي اعتمدنا عليها في هذا المبحث نظرية الحقول

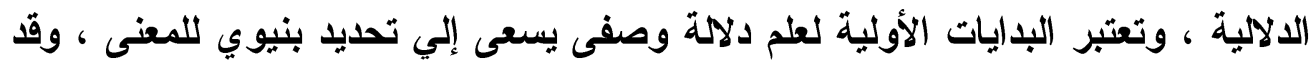

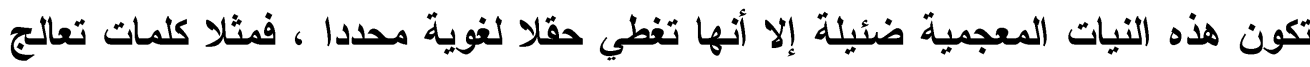
الأولوان أو الرتب العسكرية أو عبارات القرابة وغير ذلتك فإنها تخلص إلي اعتبارها مجاميع صغيرة مؤلفة من مجموعة كلمات تغطي حقلا محدودا تتكامل علاقاتها فيما بينها

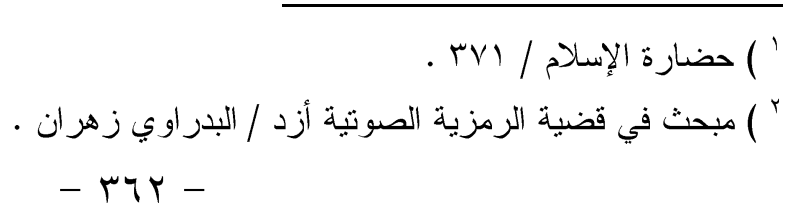


هذا ويعرف أولمان الحقل الدلالي بقوله : " هو قطاع متكامل من المادة اللغوية

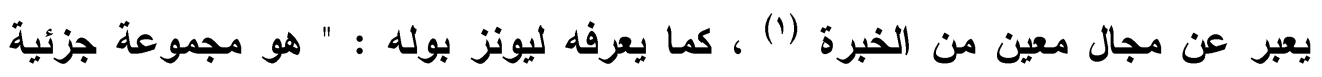
لمفردات اللغةة"(†) . وفهم الكلمة يتوقف علي مثيلاتها المتصلة بها دلاليا لأن معنى الكلمة محصلة

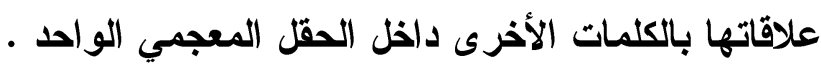
ويهدف هذا التحليل في الحقول الدلالية لي جمع الكلمات التي تخص حقدل التهل معينا وصلات عضها بيعض وصلاتها جميعا بالمصطلح العام .

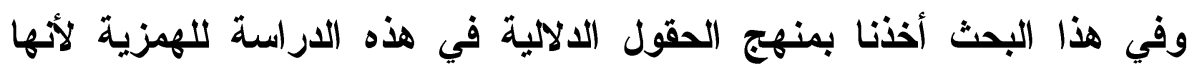

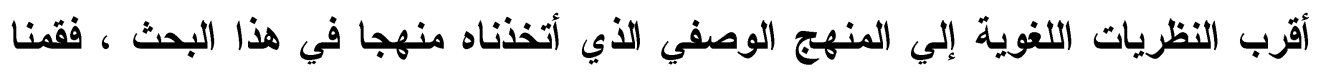

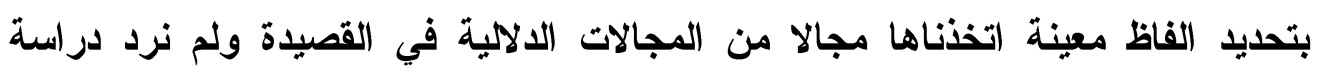

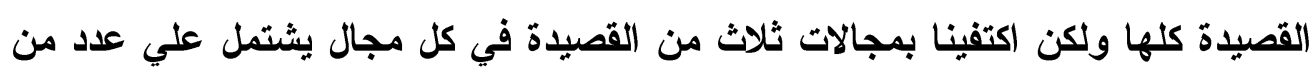

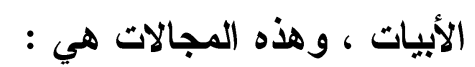

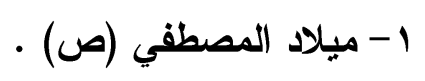

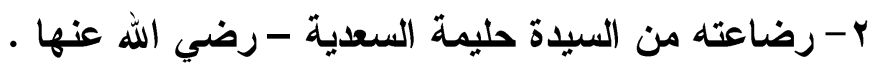

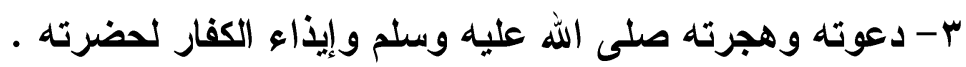

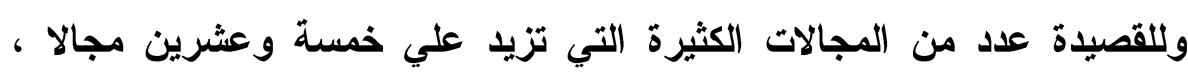
ولهذا رأينا أن نكتفي بالثلاثة المذكورة ، وقمنا باختيار مجموعة من الألفاظ لكل مجال علي حدة وشرحها شرحا معجميا دلاليا .

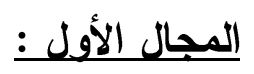
ميلاده صلى الله عله وسلم ويتناول الفاظ ( بلا - الوجود - ليلة المولد - بشري

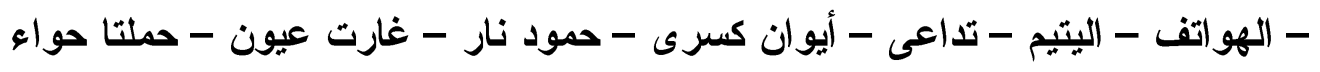

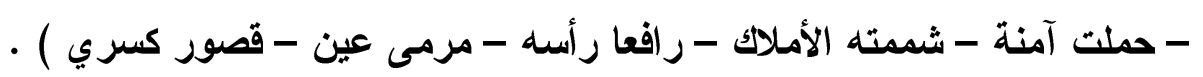




\section{المجال الثانيـ}

دعوته صلى الله عليه وسلم من السيدة حليمة - رضي الله عنها ، واتيان السيدة حليمة جده والفاظا ( رضاعة ومرضعات ورضعاء ) - شولا عجفاء - شائل عجفاء ثاويا

- الثواء - شث قلبه - مضغة - ختمته الختام - الفض و الأفضاء - نجباء ) . المجال الثالث : أثى

دعوته صلى الله عليه وسلم وإيذاء الكفار لحضرته ثم هجرته صلى الله عليه

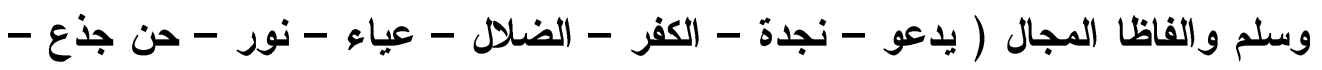

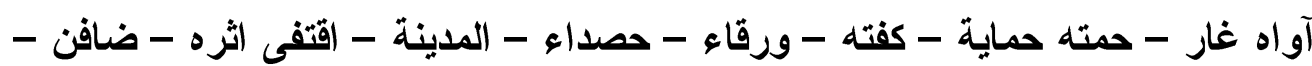
(النداء )

ونبدأ الآن في شرح معجمي دلالي للألفاظ السابقة والخاصة بكل مجال علي حدة

اللفظ المجال الأول : الان في

أيوان كسرى :

يقال الأوان والإيوان : الصفة العظيمة ، وفي الحكم : شبه أزج غير مسدود

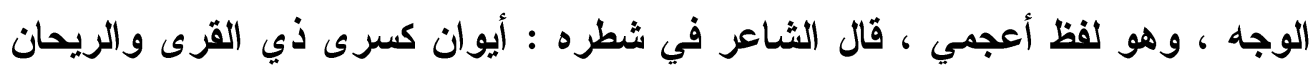
وجميع الأوان أون · وجمع ايوان أو أوين وأيونات ، وأنثد آخر : شطت فيطره : نوى من أهله

بالإيوان (')

بدأ : بدأ الثئ يبدو بدوا وبدوا وبداء أي ظهر ، وعند سيبويه بدأ ، يقول تعالى:

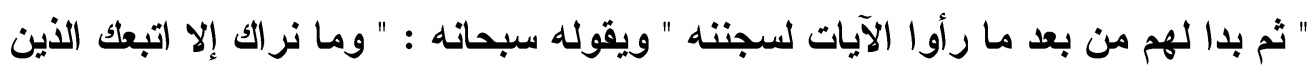

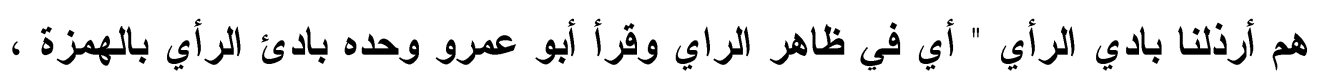
وقال الشماخ : بمان لعلك و الموعود حق لقاؤه بدا للك في تلكل القلوص بداء

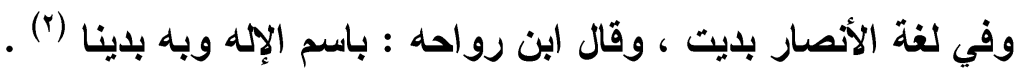

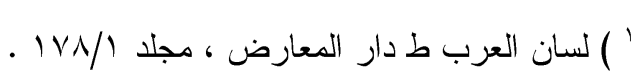

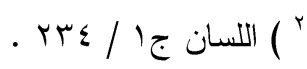


بشرى الههواتف : البشر الطلاقة ، وقد بشره بالأمر يبشره بالضم بشر أو بشورا

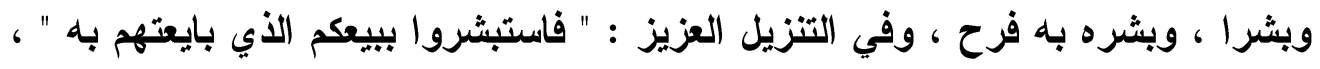

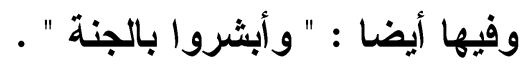
و البشارة المطلقة لا تكون ألا بالخير ، وتكون بالشر إذا كانت مقيدة كقول تعالى :

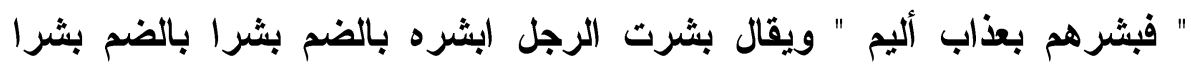

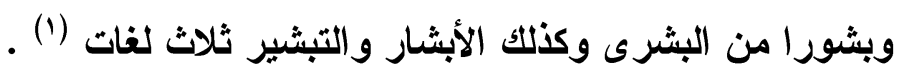
والهواتف : الهتف والهتاف : الصوت الجافي العالي ، وقيل الصوت الثديد ، وقد هتف به ، وفي حديث بدر: فجعل يهتف به " وفي حديث حنين :" أهتف بالأنصار أي وهي

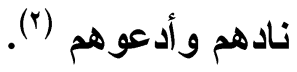

تذاعى : تداعى القوم : دعا بعضهم بعضا حتى يجتمعوا ، تقول العرب : ما

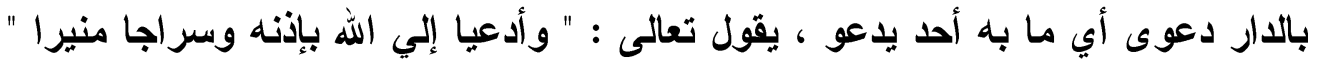

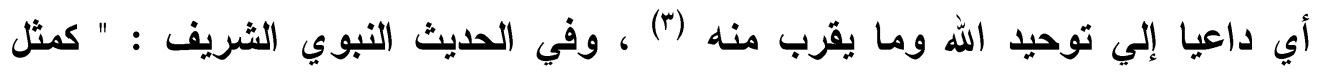

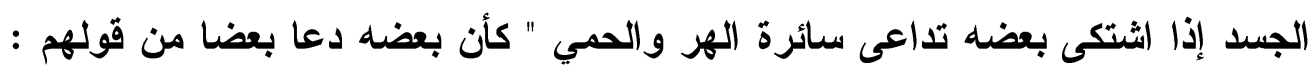

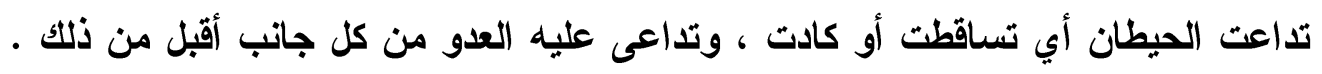

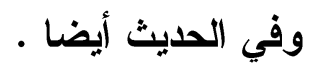

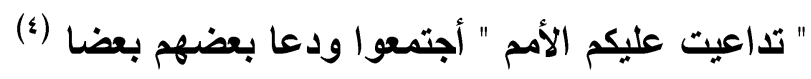

حملته حواء ( حملة آمنة ) : الحمل ما يحمل في البطن من الأولاد والجمع حمال

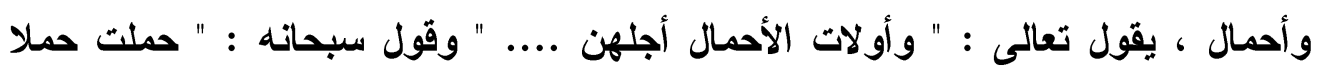

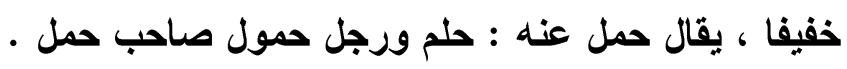

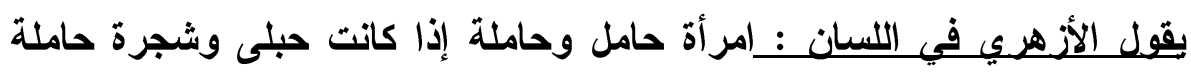
أي فيها ثمر ، واستحمله أي حمله حوائجه وأموره . وفي الحديث : " كان إذا أمرنا 
بالصدقة انطلق احنا إلي السوق فتحامل " أي تكلف الحمل بالأجرة ـ وفي حديث الفرع

و العتيرة إذا استحمل درجة فتصدقت به أي قوى علي الحمل واطاقه (1) .

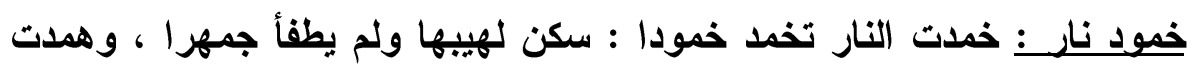

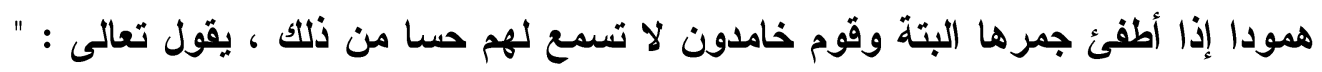

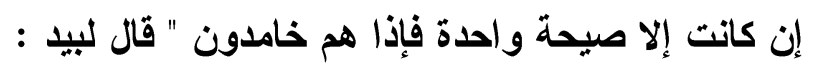

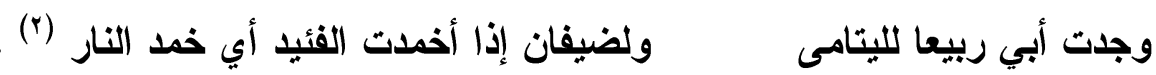
رافعار أسهة: من اسماء المولي سبحانه وتعالي الراقع أي هو الأي يرفع المؤمن

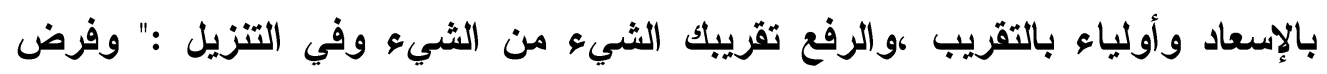
مرفوعة " أي مقربة لهم.

والمرفع أرفع السير والموضوع دونهه ، وفي الحديث النبوي الثريف :" فرفعت

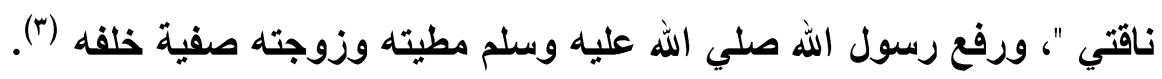

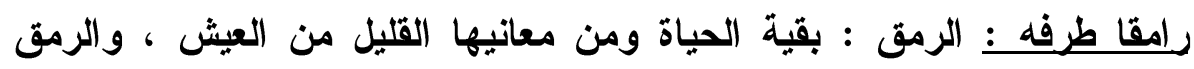

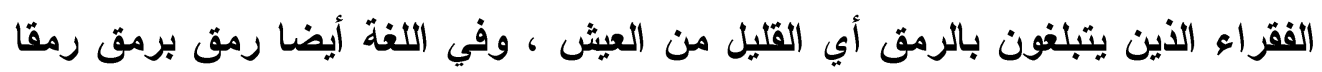

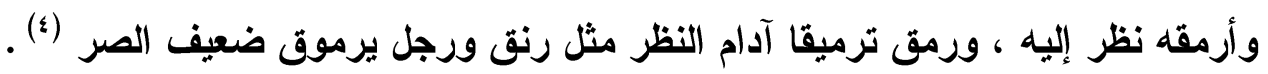

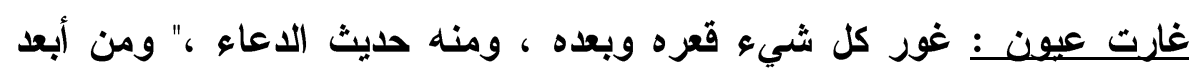

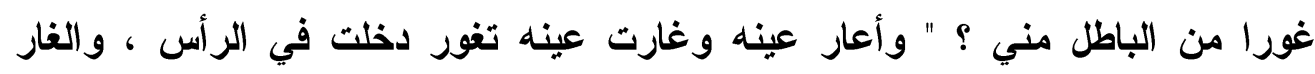
أخدود بين الجيش ، وقيل داخل الفم والغار الجميع الكثير من الناس ، وفئ وفي حديث إيث الإمام

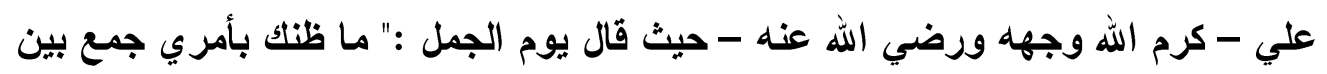
هذين الغارين ؟ أي الجيشين • ورجل مغوار أي مقاتل كثير الغارات علي أعدائه (ه) .

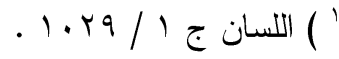

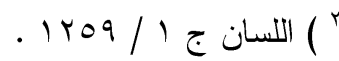

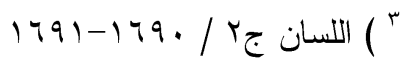

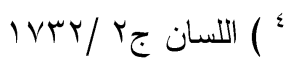

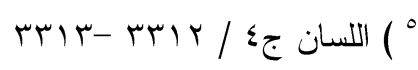


قصور كسري: من معاني القصر كفلك نفسك عن أمر ما ، وأقصر فلان عن الثيء إذا كف عنه وانتهي ، وقصر الثيء إذا كف عنه وانتهي ، وقصر الثيء حبسه ، قال تعالي :" حور مقصورات في الخيام (') . والقصر من البناء معروف وقيل المنزل وقيل الدار الواسعة المحصنة ، قال

تعالي : ويجعل للك قصورا وروي المقصورة مقام الإمام (ץ) . ليلة : الليل عصيب النها ومبدؤه من غروب الثمس وهو ضد النهار النهام ، وليلة

البلاء وليلي طويلة أي شديدة صعبة وبه سميث المرأة ليلي (r) .

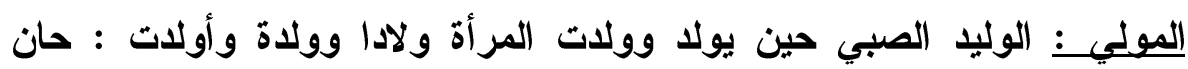

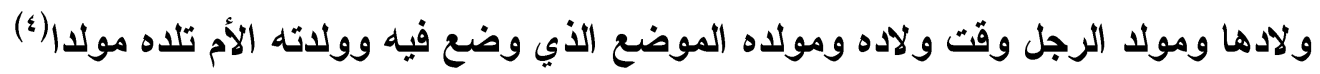

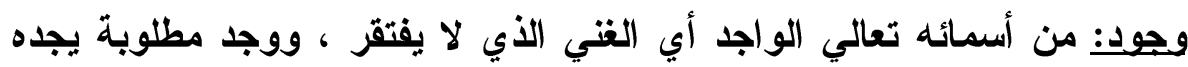
وجودا والواجد والجد اليسار والسعة ، وفي التنزيل العزيز:" أسكنوهن من حيث سكنتم

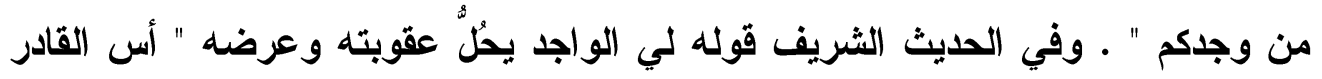

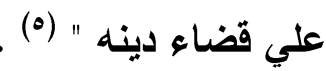
الليتبـــ اليتم الاتفر اد ، واليتم الفرد ، واليتم واليتم فقدان الأب ، قال بعض علماء

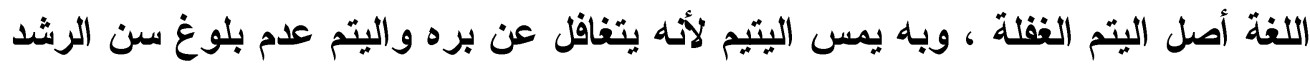

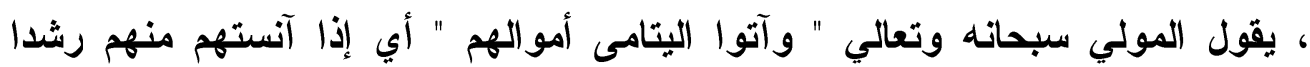
فأتوهم أموالهم ـ وفي الحديث الثريف عنه صلي الله عليه وسلم " تستأمر اليتيمة في

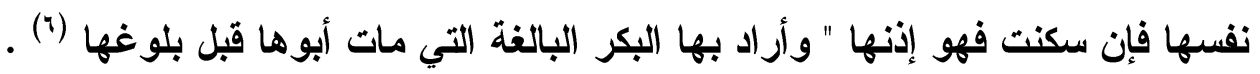

$$
\begin{aligned}
& \text { ') اللسان جع / }
\end{aligned}
$$

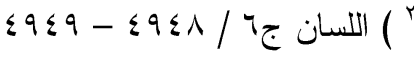

$$
\begin{aligned}
& \text { ") اللسان ج؛ } \\
& \text { ( ) اللسان ج }
\end{aligned}
$$

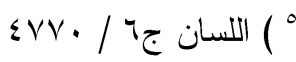

$$
\begin{aligned}
& \text { ؟ }
\end{aligned}
$$




\section{أما ألفاظ المجال الثاني : فتناولهيا كالتالي:}

ثلويا: ثوي يثوي وثويت بالمكان وثويته ثواء وثويا به أطلت الإقامة فيه ، وفي

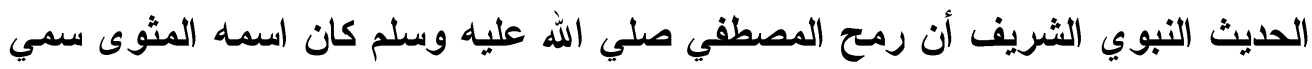

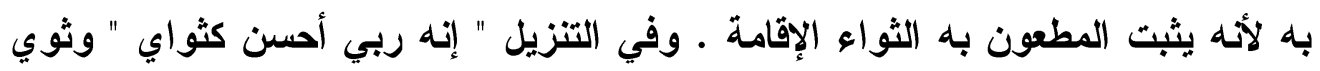

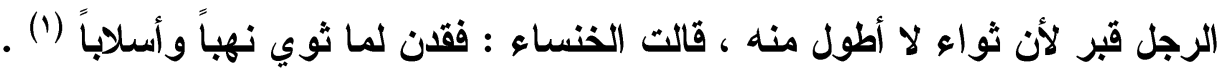

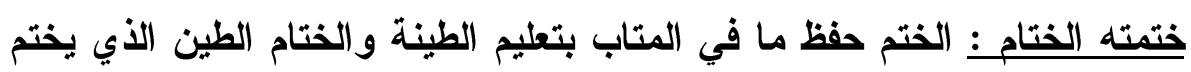

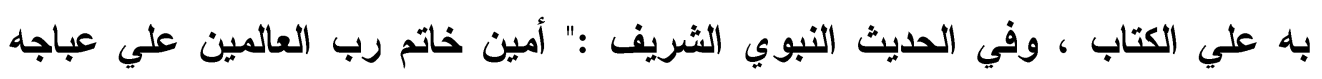

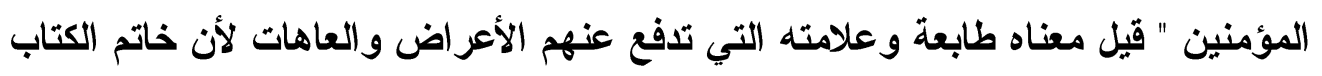

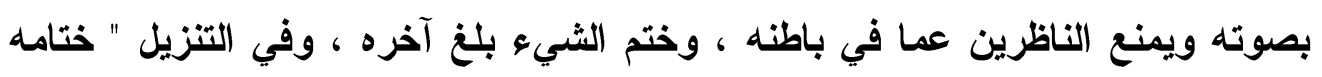

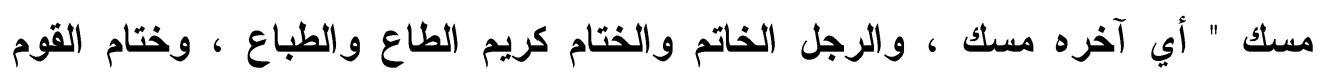

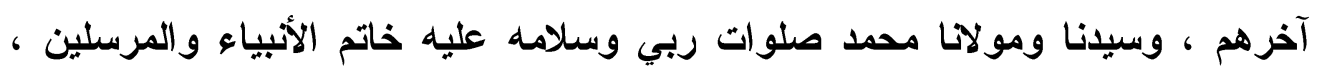

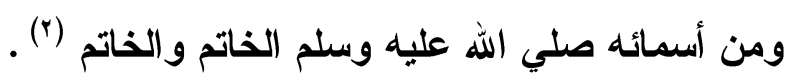

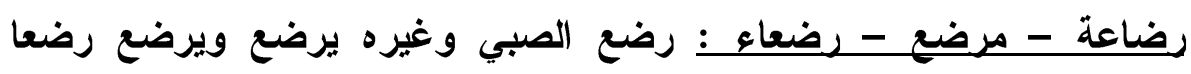

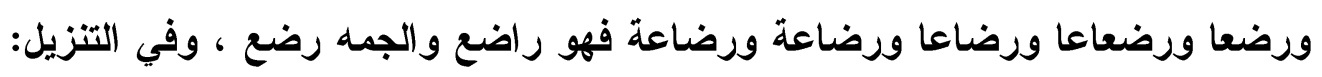

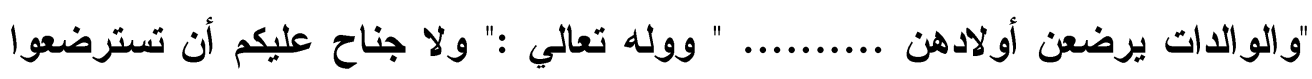

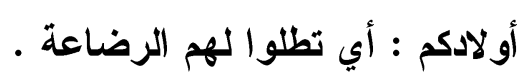

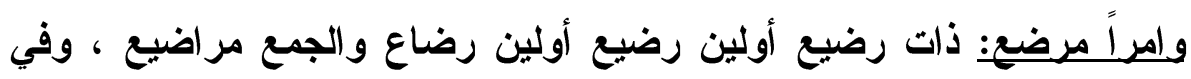

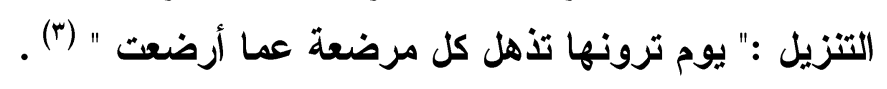

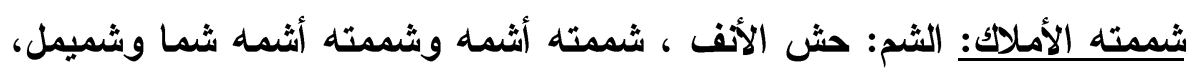

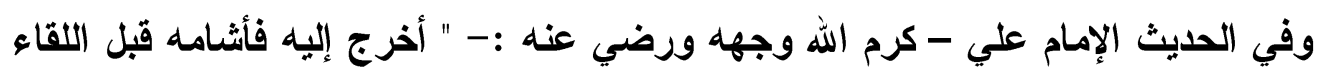

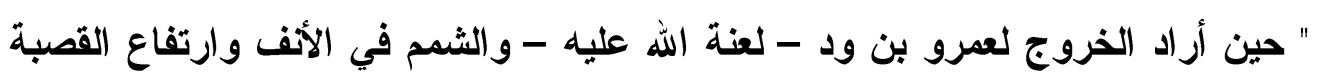

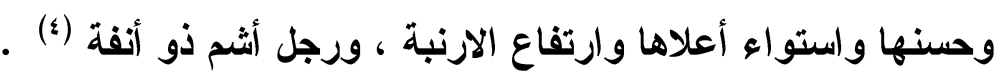

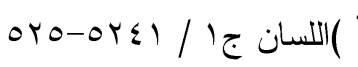

$$
\begin{aligned}
& \text { ") اللسان ج//11.1 } \\
& \text { ") اللسان جr/. }
\end{aligned}
$$

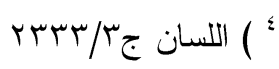


شولا عجافا (شائل عجفا): شالت الناقة بذنبها تشوله شولا وشولانا أي رفعته ،

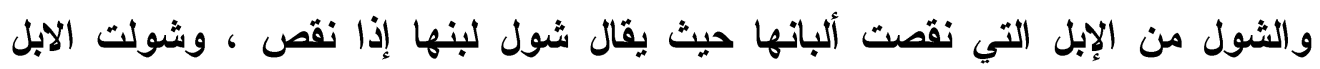
لحقت بطونها بظهورها (1). وقد بقال شوال حيث بلحق رمضان في ريط البطون والثهيوات بالصوم شتق قلبه: الشت مصدر قوللك شققت العود شقا وهو الصداع البائن ، ومن معاينه الفجر ، ويقال : هم بشق من العيش إذا كانوا في جها ، ومنه قوله تعالي :" لم تكونوا

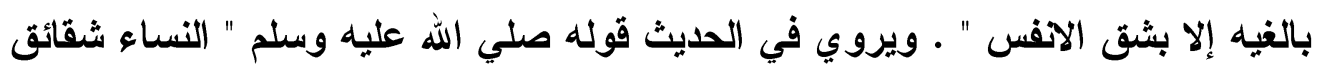

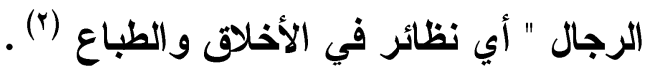
الفص والافصاء: فص الأمر : لأصله وحقيقته ، وفص الثاعل الثيء حقيقته وكنهه

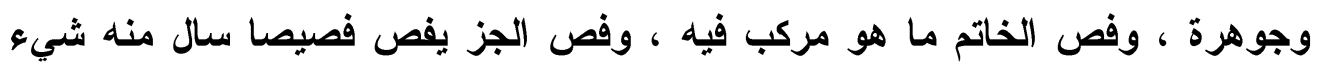

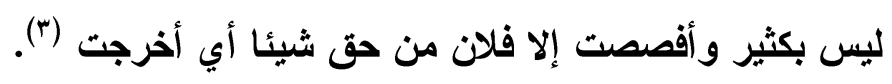

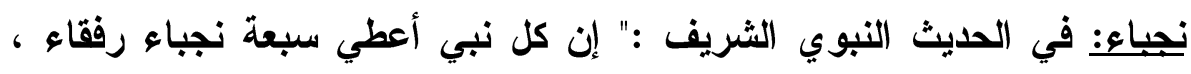

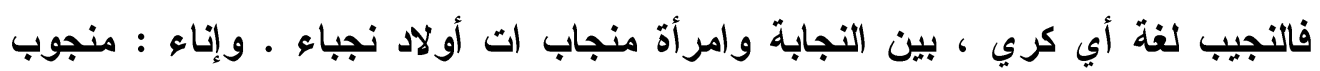

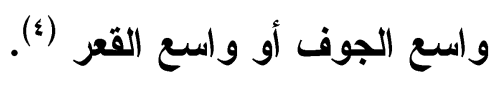

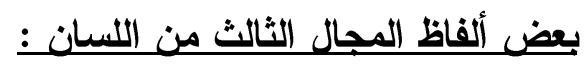

( الدعوة وإيذاء و إكفاء وهجرته صلي الله عليه وسلد )

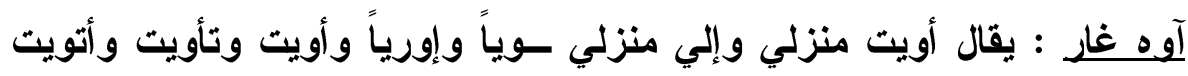
كله بمعني عدت، قال الثاعر : وعراضة الستين توبع بريها تأوي طوائفها لعجس عبهر ومنه قوله تعالي : سآوي إلي جبل يعصمني من الماء " ومنه قوله صلي الله

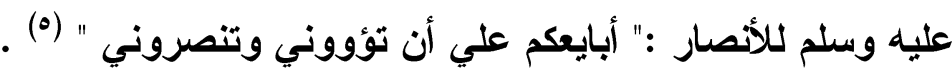

$$
\begin{aligned}
& \text { ' (للسان جr/rזrr } \\
& \text { r } \\
& \text { ") }
\end{aligned}
$$

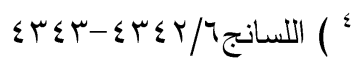

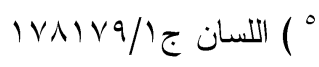


أقتفي أثره : أقتفي أثره واقتفاه : أتبعه ، وققيت علي أثره بفلان - أي اتبعته إياه ، وقفيته غيري وبغيري اتبعته إياه ، وفي التنزيل العزيز :" ثم قفينا علي آثارهم برسلنا "

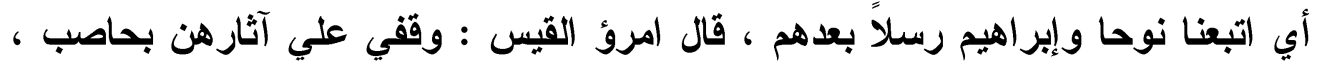

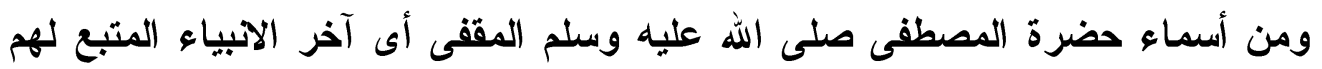

فاذا قفى فلا نبى بعده (1).

جذع الجذع : الصغير اسن ، وتقول العرب : أعدت الامر جذعا اى جديدا كما بدأ

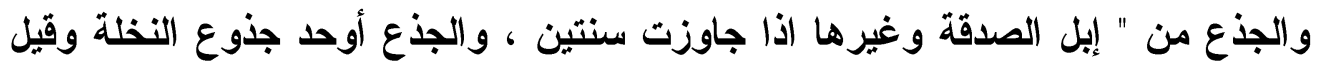
هو ساق النخلة الثئ يجذعه جزعا عفسة ود لكه ، وجذع الرجل جسه وجذعان الجبال

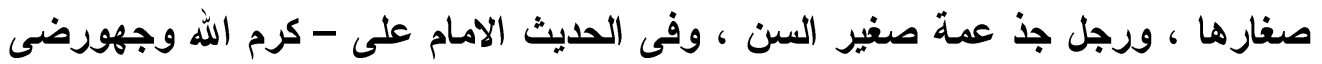

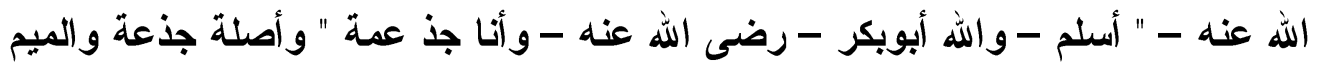

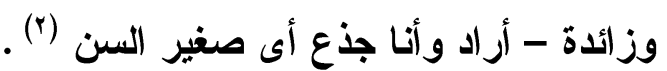
حن : الحنان من اسمائه سبحانه وتعالى بمعنى الرحيم ، والهنين أى أى الثديد من

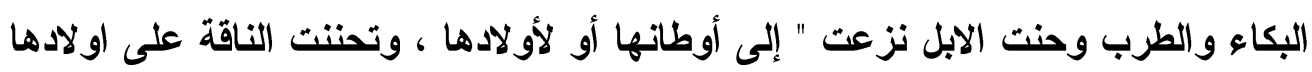
تعطت ، ويقال حن قلبى اليه فهذا نزاع واشتياق من غير صوت ولى ، وفى الحديث : " حنانيك يا رب " أى أرحمنى رحمة بعد رحمة ، وفى الحديث انه صلى الله عليه وسلم قال

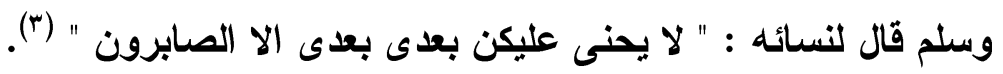

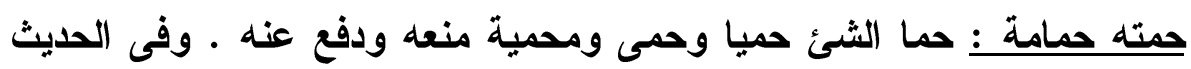

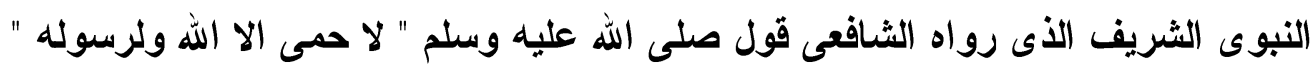

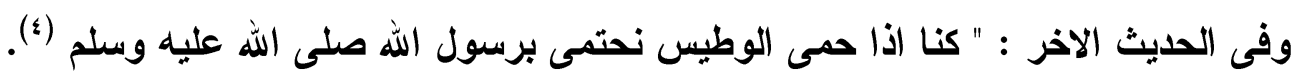
الحصداء: الحصد هو جزل البر ونحوه من البنات يحصده وحصادا قطعته بمنجل ونحوه ، وحصداء وزن فعلاء من الحصد ، وحصاد كل شجرة ثمرتها ، والحصيد

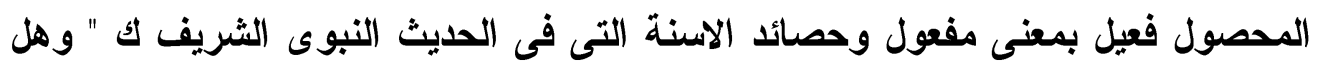

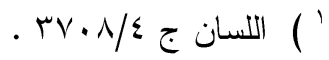

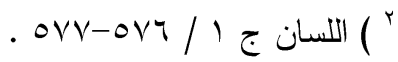

$$
\begin{aligned}
& \text { r }
\end{aligned}
$$

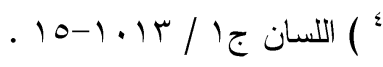




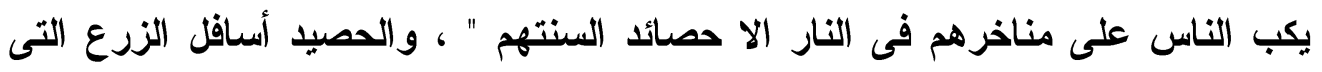

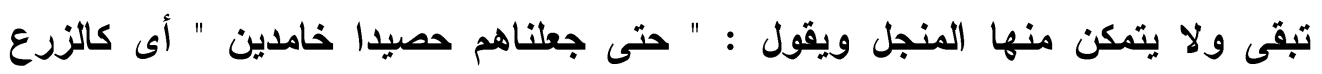

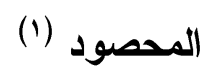

يلدعو : الدعاء الرغبة الى الله تعالى دعاه دعاء ودعوى ، قال تعالى : " وأدعوا

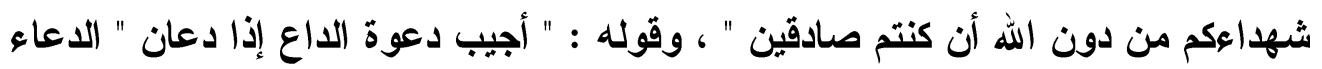

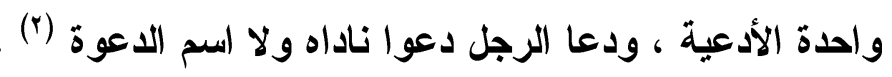
صافن جرداءء : الصافن عرق من باطن الصلب طولا منصل به نياط القلب

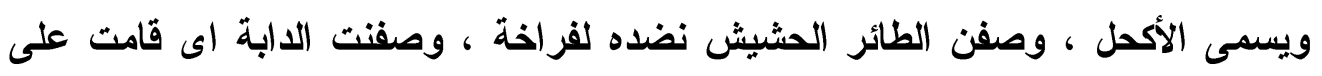

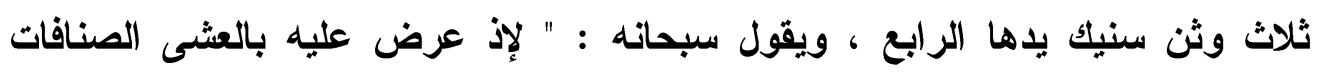

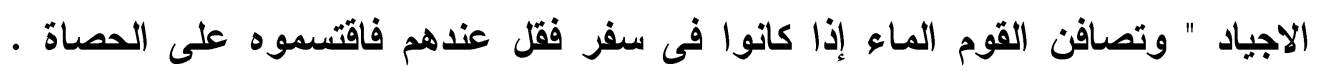
وعلى ذلك اصافن الجرداء " أى الناقة الجرداء " (r).

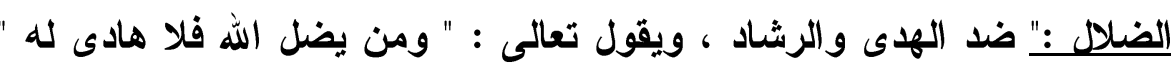

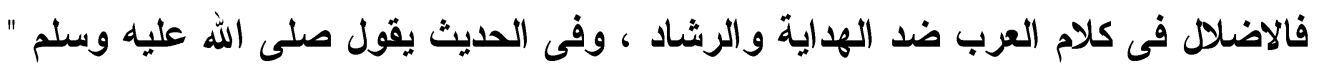

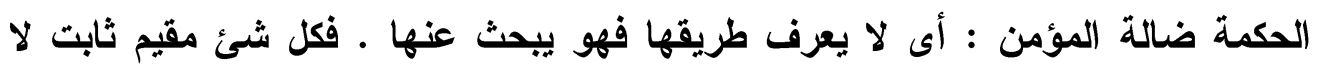
تهندى اليه فهو عنك وضل وأضلك الثئ اذا وجدته ضالا ، ومنه الحديث : أن النبى

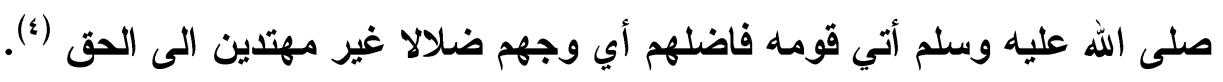

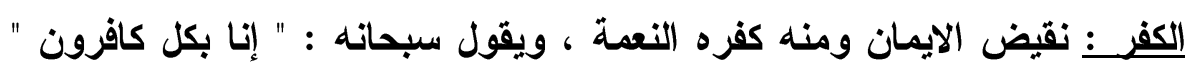
وأصله فى اللغة تغطية الثئ تغطية تستهلكه ، وكل من ستر شيئا فقا كفره ، فالمزارع

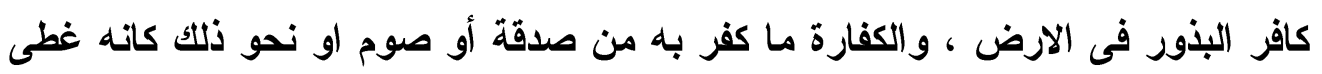
عليه بالكفارة (•)

\begin{tabular}{|c|}
\hline ' ) اللسان ج) / \\
\hline 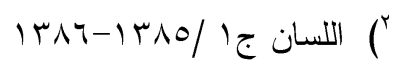 \\
\hline 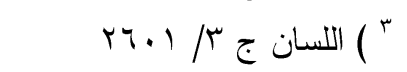 \\
\hline 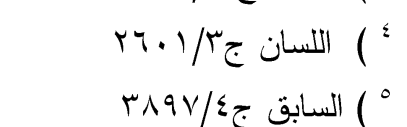 \\
\hline
\end{tabular}


المدنبة : مدن المكان أقام به ومنه المدينة ، والمدنية اسم مدينة رسول الله صلى الله عليه خاصة شرفها الله وصانها ، وغلبت عليها تفخيما ، ، وتعظيما لها ، ويقال للامة مدينة اى مملوكة لها ، فكان المدينة المنورة مملوكة لحضرة المصطقى صلى الله عليه وسلم (1)

نجدة : أنجد فلان الدعوة : أجابها ، ونجد الامر ينجد نجودا وضح واستبان ، والنجدة الثدة ، والرسل : ما دون ذل مكن الثدة ، وفى حديث المصطفى صلى الله عليه

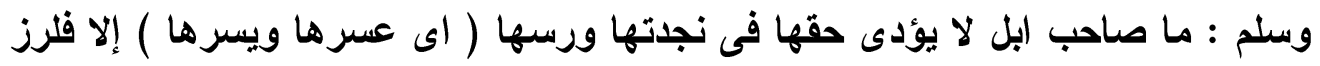

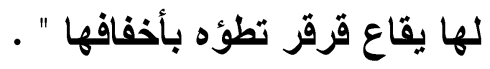
والنجدة : الشجاعة والمناجد المقاتل والنجاد ما وقع على العاتق من حمائل

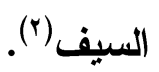

نور : من اسمائه جل فى علاه النور ، وهو الذي يبصره بنوره ذو العماية ، ويرشد بهداه ذو الغواية ، ويقول الله تعالى : " الله نور السموات والارض " وضده وند نار نورا

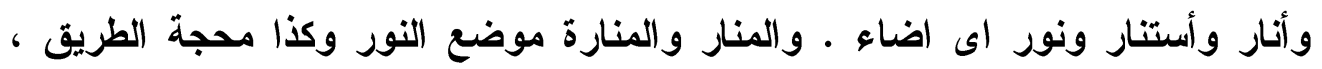
والنور المصطفى (ص) كان أنور المتجرد (اع). نداء : نده الرجل ينده ندها اذا صوت ، ومنه الزجر ومنه كثرة المال من صامت

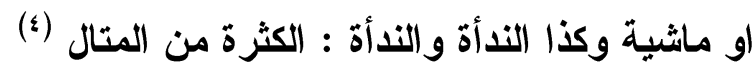

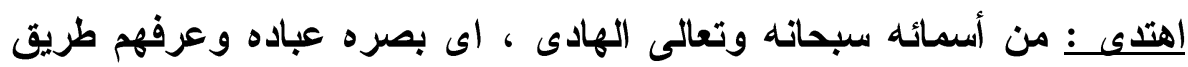
معرفته ، وهدى واهتدى بمعنى واحد يقول تعالى : " وإن لغفار لمن تاب وآمن وعمل

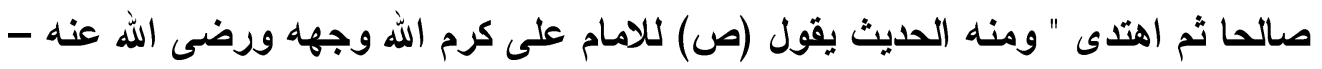
سل الله الهاى " ، وفى رواية " قل اللهم الهنى وسددنى ، واذكر بالهاى هدايتك الطريق الطريق وبالسداد تسديدك السهم".

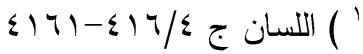

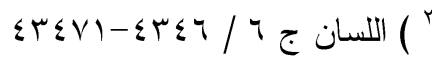

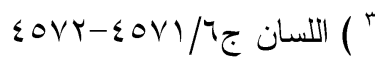

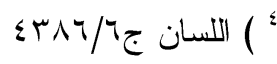


وهدى فلان اي سار سيره واستن سنته ، وفى حايث ابن مسعود " إن أحس (1)

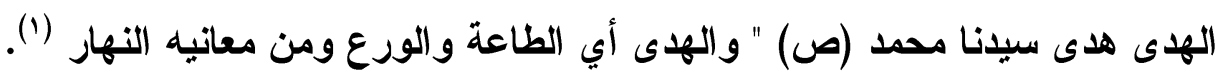

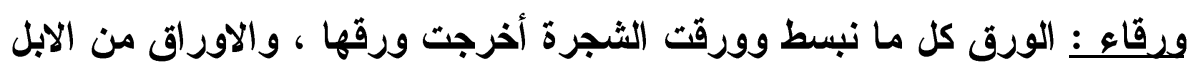

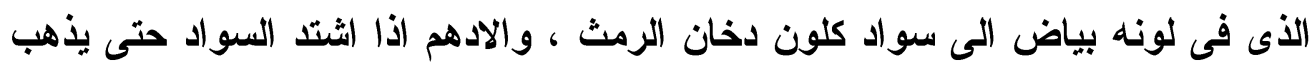

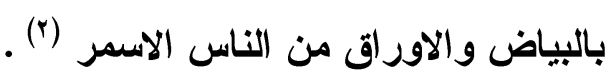
أما بالنسبة لابيات هذه المجالات الثلاث فهى مأخوذة من كتاب شرح الهنم الهزية فى الهي مدح خير البرية (ص) للإمام البوصيري ، شرح العلامة محمد شلبي وهو كتاب مقتبس لهابس

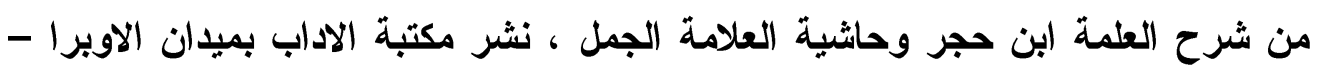
مصر.

وابيات المجال الاول تبدأ من البيت التاسع من القصيدة وحتى البيت السابع والعثرين وابيات المجال الثاني من البيث الثامن والعشرين ، وحتى البيت الخامس لبان والربعين والمجال الثالث من البيث السابع و الخمسين وحتى البيت الثاني والسبعين . ويصعب علينا شرح البيات ، فالمديح وان كان عنصرا من عناصر الثعر العربي وني ولئي

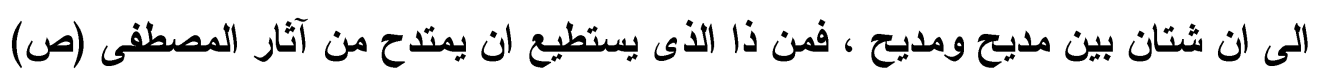

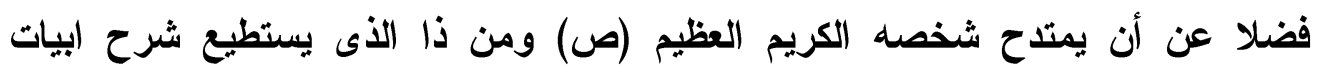

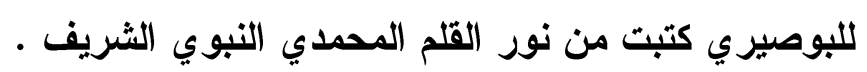
ولذا اكتفينا بهذا التحليل الوصفى القائم على نظرية الحقول الدالية واخترنا ثلاث

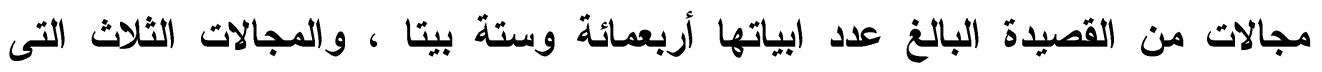

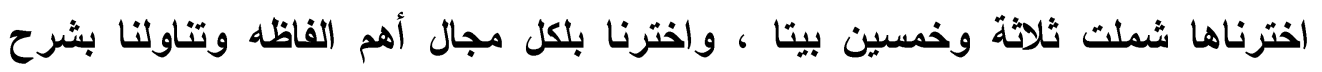

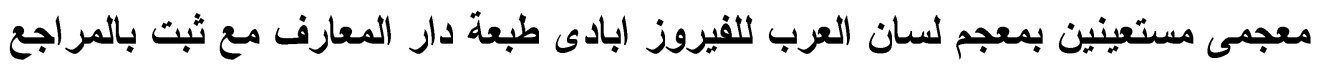
الاساسية التى تناولت نظريات التحليل الدلالى ومنها نظريات الحقول الدلالية . 


\section{أهم المراجيع العربية :}

1) علم الالالة أ.د / أحمد مختار عمر - مكتبة دار العروبة .

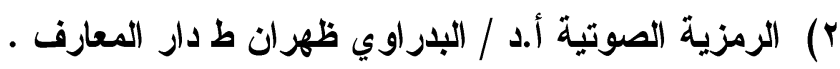

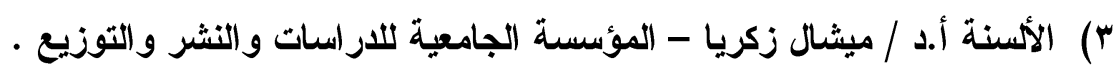

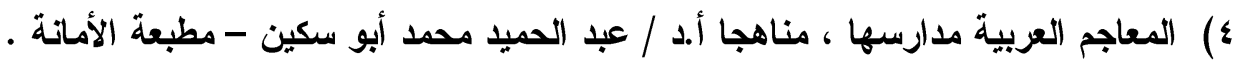

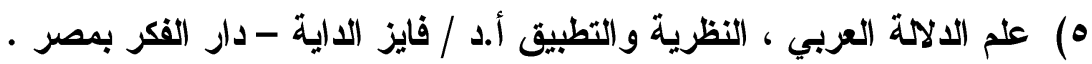

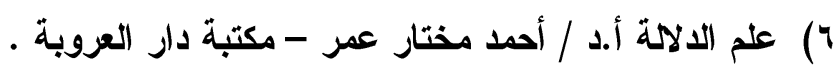

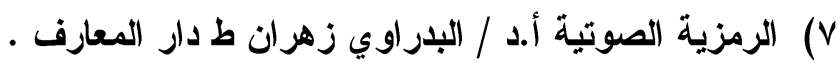

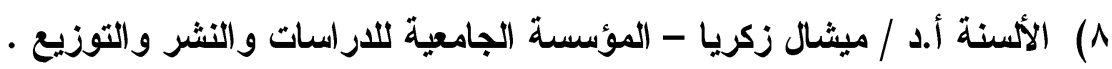

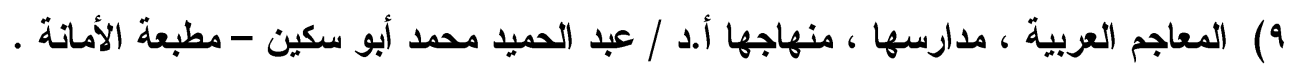

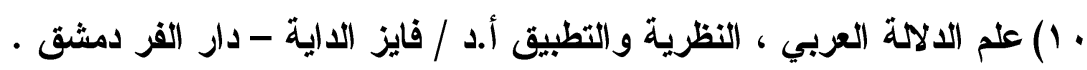

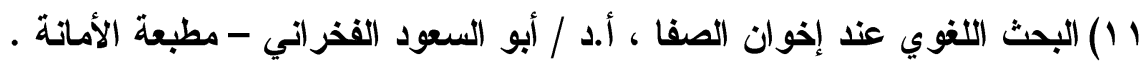

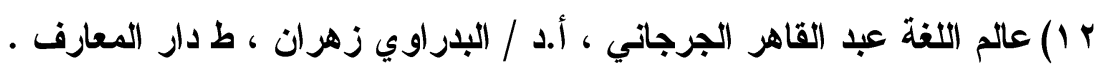

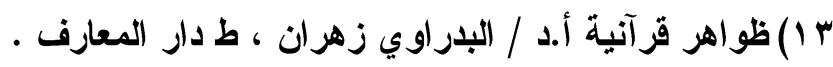

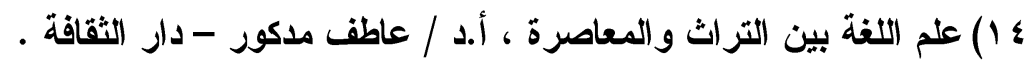

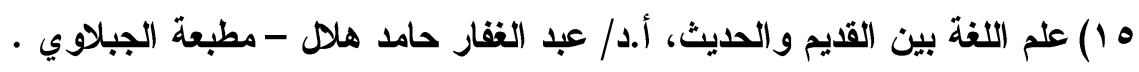

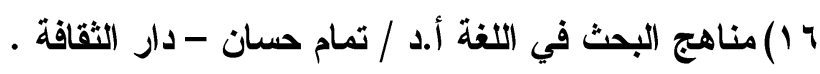

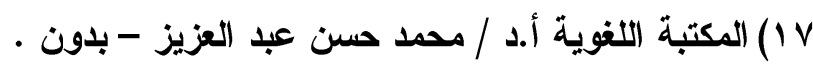

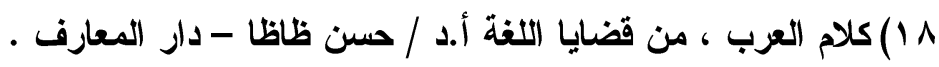

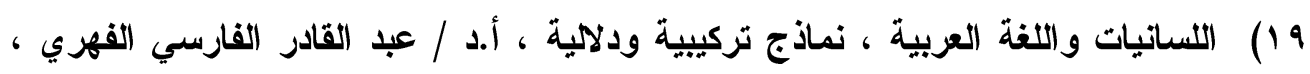

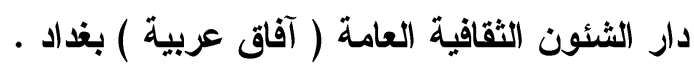

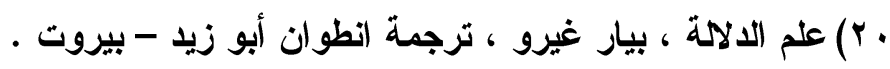

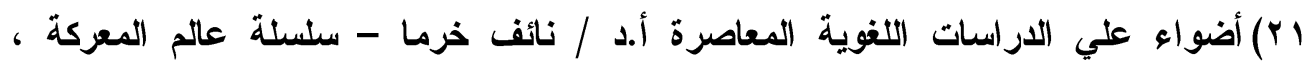
الكويت. 